\title{
Looking Back at Social Discounting Policy: The Influence of Papers, Presentations, Political Preconditions, and Personalities
}

\author{
Ben Groom* and Cameron Hepburn**
}

3 May 2017

\begin{abstract}
Over the past 15 years, government guidelines on social discounting for benefit- cost analysis have been updated in many different countries. These updates appear to reflect the influence of important academic contributions recommending the use of a declining term structure of discount rates. Using qualitative evidence from the UK, US, France, and the Netherlands, this article shows that the influence of this academic supply-side would not have been possible without the policy demand-side, and the presence of institutional or charismatic policy brokers acting as policy market-makers. We argue that the market analogy is a useful framework for academics seeking to influence policy with their research.
\end{abstract}

JEL-Classification: H43, D61

Keywords: Social discount rate, Declining Discount Rates, international experience, policy making, policy entrepreneurs, policy windows.

\footnotetext{
* London School of Economics and Political Science, UK; e-mail: B.Groom@lse.ac.uk

${ }^{* *}$ Smith School of Enterprise and the Environment and the Institute for New Economic Thinking at the Oxford Martin School, University of Oxford, UK; London School of Economics and Political Science, Grantham Research Institute UK; e-mail: cameron.hepburn@new.ox.ac.uk We are grateful to the experts and officials (see Appendix 1) who participated in interviews for this paper. We thank participants at the Department of Geography and Environment/Grantham Research Institute memorial conference for David Pearce, held in September 2015, and all participants in the discounting policy panel session held at EAERE 2016 in Zurich for lively discussion and helpful comments. In particular, we express gratitude to co-presenters Phoebe Koundouri, Christian Gollier, and Aart de Zeeuw. We also thank but do not implicate Richard Perkins for his review of an earlier draft. Finally, we express our gratitude to Ed Barbier, Ian Bateman, and David Simpson for encouraging us to pursue this paper.
} 


\section{INTRODUCTION}

The long-term is becoming more important. This is the conclusion suggested by changes made to the official guidance for discounting in project and policy appraisal in the United Kingdom (HMT, 2003), France (Lebègue, 2005) and Norway (Hagen et al, 2012), among others, ${ }^{1}$ where the discount rate applied to costs and benefits in the distant future is lower than the discount rate applied today (generally referred to as a declining discount rate or DDR).

These policy changes reflect advances in the theory of discounting (e.g. Gollier, 1997, 2002a,b, 2004; Weitzman, 1998), which had generally remained untouched since the initial formalisations of Samuelson (1937) and Koopmans (1960; 1972). These new ideas in the theory of discounting have been developed, deployed, and diffused like never before, and the all-too-frequent gap between the "supply" of ideas from academia and the "demand" for them from policymakers seemed to close.

It is tempting to conclude that these policy changes represent a triumph of the application of economic theory and the influence of academics within governments. But is this conclusion warranted? What, if anything, can be learned from the recent experience with social discounting for the application of economic theory in other domains? This article seeks to shed light on the influence of academic work on DDRs relative to the other factors that determine policy changes and development. Our working hypothesis is that the changes to discounting guidance, in which we were both personally involved (Oxera, 2002; Pearce et al. 2003), occurred through the combined influence of key papers, presentations, political preconditions, and sometimes individual personalities. Although teasing out the contributions of these factors in this non-linear and uncertain process is not straightforward, it is nevertheless important. In particular, economists interested in the process of enslaving

\footnotetext{
${ }^{1}$ In 2013, for instance, the Danish guidelines were updated in line with the Norwegian guidelines: https://www.fm.dk/nyheder/pressemeddelelser/2013/05/ny-og-lavere-samfundsoekonomiskdiskonteringsrente
} 
'practical men' prior to becoming defunct (Keynes 1936) need an understanding of how new economic ideas are translated into policy change and hence real-world impact.

In order to test our hypothesis, we conducted interviews with a dozen key policy actors (see Appendix 1), which we used to support a qualitative analysis of the policy changes that took place in the UK, US, France, Norway, and the Netherlands over the last 15 years. Our qualitative analysis is framed by the large literature on the process of policy change, which we parse into a framework emphasising the idea that policy making and policy change has both a supply side (academic ideas) and a demand side (from policy makers). Our approach also emphasises the role of policy brokers -- the key personalities and their presentations -who bring the demand and supply sides together to facilitate change.

We organize our discussion as follows. The next section provides some background on the theory of policy change and our demand-supply-broker framework. A summary of the key contributions to the theory and empirics of DDRs follows. We then analyse the initial deployment of the DDR in the United Kingdom by Her Majesty's Treasury (HMT, 2003), which is followed by an examination of what we argue is a diffusion/policy transfer of the idea of DDRs to the other countries that we study. In the final section, we present conclusions and discuss lessons for academics whose objective is to influence policy. A key conclusion is that all three components of the ideas market - policy brokers (or intellectual intermediaries), along with the demand- and supply-side dynamics, are necessary for policy change.

\section{THE ANALYSIS OF POLICY CHANGE: BACKGROUND AND FRAMEWORK}

There is a large literature on the process of policy change. We outline five key concepts here. First is the policy entrepreneur (Mintrom, 1997) -- a motivated individual who identifies policy problems, creates solutions and then persuades and organises other individuals to implement those solutions. Second, is the notion of the policy window (Kingdon and 
Thurber, 1984) -- the point in time that is right for policy change. The third concept is the advocacy coalition framework (Sabatier, 2006), in which coalitions of individuals with different roles (researchers, interest group leaders, civil servants and elected officials) but shared beliefs coordinate to achieve change that is in their interests. Fourth is the slippery concept of power, which is frequently argued to stem from expert knowledge (e.g. Foucault 1991). However, it can also emanate from the charismatic authority of individuals, or from rational-legal authority, when institutional structures are more important than individual personalities (Waters and Waters 2015). Finally, policy transfer (Dolowitz and Marsh, 2000) across jurisdictions is also a key concept in the process of policy change.

In this article, we present and use a complementary, economic lens to understand policy change. More specifically, we would argue that public policy change involves the forces of supply and demand in a market for ideas. Through this lens, R\&D provides the supply of new ideas (delivered in papers and presentations), political preconditions dictate the demand for an idea at a specific point in time, and, most vitally, energetic and persuasive personalities help to overcome political, intellectual, or even administrative barriers that prevent the ideas market from operating efficiently. Arguably, such personalities have power in the form of expert knowledge and legitimacy. ${ }^{2}$

The five concepts outlined earlier can be related to our economic lens as follows. In many ideas markets, brokers and other intermediaries (i.e., policy entrepreneurs) bring together demand and supply to close the deal. 3 The demand for ideas fluctuates with exogenous conditions (i.e., the policy window). Coordination by various players (i.e., an advocacy coalition) is often needed to crystallise the demand and provide the supply of ideas. In the case of discounting, our interviews suggests that the power of the brokers was critical, whether this power resided in formal institutions or in charismatic individual brokers with

\footnotetext{
${ }^{2}$ Similar ideas can be found in Braun (2009), who analyzes the birth of the European carbon emissions trading system.

${ }^{3}$ Ideas markets are not necessarily efficient; good ideas can be underprovided and bad ideas overprovided, and market manipulation by policy entrepreneurs is possible (Kingdon, 1995).
} 
intellectual authority. The brokers often straddle the academic/R\&D and policy sphere, and make timely presentations and other interventions to key policymakers, including those from different jurisdictions, thus facilitating policy transfer. With this background on the theory of policy change and our framework, we next examine the supply of ideas that changed discounting policy.

\section{THEORETICAL AND EMPIRICAL FOUNDATIONS OF DDRS}

This section examines the supply of ideas by reviewing the key articles in the economics literature that influenced discounting policy over the past 15-20 years. We consider an article to have 'influence' if it meets at least one of the following three (sometimes overlapping) criteria: 1) it is cited in government guidelines on DDRs; 2) the article or article's author(s) is consistently referred to by interviewees; 4 and 3) an article is considered, by virtue of originality and academic citations, to be foundational for social discounting and DDRs. We refer to the period during which these key articles were published as the R\&D phase. 5

\section{Early R\&D on Discount Rates}

The R\&D phase arguably began in the 1950 s and 1960s, as governments began to use benefit-cost analysis (BCA) to examine major infrastructure investments (water, energy, and transport). Inevitably, the results of these analyses were highly sensitive to the discount rate, and thus research on discounting took off (e.g., Feldstein 1964). The major contributions from this period were subsequently published by Resources for the Future (RFF) as Lind (1982a). The conclusion of the opening chapter (Lind, 1982b) was that the appropriate discount rate for long-term projects should reflect the shadow price of public capital. Lind (1982a) was the go-to reference on social discounting until 1999, when RFF held a symposium on social discounting and inter-generational equity. This resulted in publication

\footnotetext{
${ }^{4}$ See Appendix for a list of interviewees and their institutional affiliations.

${ }^{5}$ The on-line Supplementary Materials includes a table that lists these articles, their citation counts, and citations in policy documents.
} 
of an edited volume (Portney and Weyant, 1999), with chapters by Schelling (1999) on ethical trade-offs within and between generations, and Arrow (1999) on public investment as an inter-temporal game. The symposium (Portney and Weyant 1999) also considered whether the discount rate should be constant for distant time horizons.

\section{Experimental and Behavioral Economics}

Despite not being directly relevant to social discount rates, behavioural economic concepts and empirical studies alerted academics and practitioners to the phenomenon of nonexponential individual discounting, whereby individual discount rates depend on the time horizon being considered (Loewenstein and Prelec 1992). Empirical evidence of individual hyperbolic discounting (Cropper et al 1994; Cropper and Laibson 1999) was consistent with research in economic psychology and evolutionary biology (Ainslie 1992, Thaler 1981, Frederick et al. 2002) and suggested that individual discount rates decline over time. Such findings were contrary to the standard assumption of constant discount rates, and declining discount rates were used to explain irrational behaviour such as loss of self-control, addiction, and procrastination. Some argued that if BCA is to reflect the preferences of the population, perhaps the standard assumption of exponential discounting needed to be revised (Henderson and Bateman 1995).

Ultimately, however, the behavioural economics literature was not decisive in the move toward DDRs at the policy level. It was questioned whether a behavioural theory that explained irrational behaviour was a suitable basis for government guidance (Henderson and Bateman, 1995). Furthermore, these behavioural phenomena were typically observed over time horizons measured in days and weeks, rather than years or decades (Frederick et al., 2002), which are generally the relevant time horizons for BCA of government projects.

\section{The Term Structure of Interest Rates}

The economic literature on the term structure of interest rates (which explains the profile of interest rates at future points in time) had the greatest influence on discounting policy, 
especially the theoretical work by Gollier (2002a, 2002b) and Weitzman $(1998,2001){ }^{6}$

Using a highly ‘stripped down’ model, Weitzman $(1998,1999)$ argued that planners should use a declining term structure of social discount rates (i.e., DDRs) when the discount rate itself is uncertain. His straightforward formal exposition and empirical applications caused these ideas to become very influential. However, there is only limited theoretical support for Weitzman's argument (e.g., Traeger 2011). It is not clear, for instance, why the expected net present value criterion (ENPV), which is central to Weitzman's argument, is a natural welfare criterion. Weitzman's approach is, in fact, a quite special case of the standard theoretical literature (e.g., Gollier and Weitzman 2010). ${ }^{7}$

In contrast, Gollier (2002a,b) extended the seminal contribution of Lucas (1978) concerning the theory of asset pricing. ${ }^{8}$ While Weitzman (1998) argued definitively for DDRs, Gollier (2002a, 2002b) isolated the requirements for uncertainty of growth and the risk preferences of the representative agent that would lead to different term structures, including DDRs. The essential argument for DDRs due to uncertainty of growth is that persistent shocks to growth increase future uncertainty and hence the precautionary motive for saving. Later, the many theoretical arguments for DDRs were compiled in Gollier (2008, 2012).

While considerably more technical than Weitzman (1998), citations and qualitative evidence from interviewees indicate that the earlier Gollier (2002a, 2002b) papers strongly influenced the 2003 update to the UK Green Book, while his later work (Gollier 2008, Gollier 2012) was the foundation for the advice to the French government (discussed in detail later).

\footnotetext{
${ }^{6}$ Their work has been heavily cited in government guidelines (IAWG 2010, HMT 2003, Hagen et al. 2012, USEPA 2010) and in academic work (See table in Supplementary Materials).

${ }^{7}$ Freeman and Groom (2016) and Gollier (2016) discuss the theoretical motives of Weitzman (1998). See also Cox, Ingersoll and Ross (1981). A survey of contributions at the time can be found in Groom et al. (2005).

${ }^{8}$ Gollier's research was triggered by a request from the French government to evaluate public investments in nuclear power. With decommissioning horizons of 150 to 1000 years, a precise theory of the appropriate social discount rate was necessary.
} 


\section{Estimating DDR Schedules}

Changes to policy guidance typically require empirical evidence to support them. Using a time series interpretation of Weitzman (1998), Newell and Pizer (2001; 2003) estimated a term structure of DDRs by calibrating uncertainty in discount rates using the historical (200 year) time series of risk-free interest rates in the US. Subsequent papers applied the same framework (but alternative empirical models) to US interest rate data, with extensions to the UK and other OECD countries (Groom et al. 2004; 2007; Hepburn et al. 2008).

An important but controversial contribution to empirical research was the Weitzman (2001) "Gamma Discounting" proposal, which surveyed 2000+ experts on the appropriate "interest rate" for discounting climate change projects. The expert opinions were then used to proxy uncertainty in the discount rate and to calculate the certainty equivalent discount rate. For horizons of 300 years, the term structure declined from $4 \%$ to $1 \%$. Although numerous concerns have been raised about gamma discounting (Freeman and Groom 2015; Heal and Millner 2013; Gollier 2016), its simplicity contributed to its policy influence.

\section{Summary}

To summarize, the R\&D phase supplied important new ideas about discounting. This phase was dominated by Weitzman (op. cit) and Gollier (op. cit), although many others made contributions. ${ }^{9}$ It would be a mistake, however, to view the supply of new ideas about discounting as being completely exogenous. Rather, these ideas were triggered by the growing importance of long-term public policy issues - particularly climate change mitigation and adaptation, and nuclear power. The sensitivity of long-term project appraisal to the social discount rate alerted academics and policy-makers alike to the possible limitations of standard discounting theory.

\footnotetext{
${ }^{9}$ See Groom et al. (2005) for a summary of these contributions.
} 


\section{INITIAL DEPLOYMENT OF THE DDR IN THE UNITED KINGDOM}

In this section, we apply the demand-supply-broker lens to the UK, which was the first government to change its guidelines on social discounting to DDRs. In 2003, Her Majesty's Treasury (HMT) implemented two major changes in discounting guidance for government departments through an update of the "Green Book," which provides guidance for the appraisal and evaluation of projects and regulations that all departments are required to follow. ${ }^{10}$ First, the discount rate for short time horizons was reduced from $6 \%$ to $3.5 \%$. Second, DDRs were introduced, with the forward rates declining in steps from $3.5 \%$ to $1 \%$ for horizons of 300 years or more (see Figure 1a). ${ }^{11}$

There was no guarantee ex ante that these changes would actually be implemented.

Changing the discount rate in the Green Book affects appraisal across all departments, and changes to the guidelines with such broad impacts have always been subject to inertia within the Treasury. Qualitative evidence from our interviewees suggests that the successful implementation of the new Green Book guidance depended on three key factors: 1 . the prevailing political conditions (the demand side); 2. the presence of economic ideas of high perceived quality (the supply side); and 3. some key personalities (brokers). We consider these three factors in turn.

\section{The Role of Political Conditions}

Interviewees that were involved in the Green Book update suggest that changes to the UK's discounting guidance were due in part to the prevailing political winds. In particular, the

\footnotetext{
${ }^{10}$ Formally, the document is "The Green Book: Appraisal and Evaluation within Central Government" (HMT 2003).

${ }^{11}$ The full schedule: for horizons $H=[30,75,125,200,300]$ the period-to-period discount rate is $[3 \%, 2.5 \%, 2 \%$, $1.5 \%, 1 \%]$.
} 
recession of the early 1990 s and the government's austerity measures led to concerns among civil servants and politicians about the state of the country's infrastructure. From 1997 onwards, the new Blair government was particularly concerned about modernisation and productivity. ${ }^{12}$

Some civil servants were concerned that the existing Green Book discounting guidance discriminated against public projects with long-term objectives (e.g., increasing productivity). More specifically, despite specific guidance suggesting the contrary (See HMT 1997, Annex G, paragraph 4), it was widely believed in government departments that the 6\% discount rate included a premium for so-called 'optimism bias', a term used to describe the phenomenon of project benefits being systematically overestimated or costs underestimated. ${ }^{13}$ There was also concern (e.g, within the Department of Transport) that the 6\% discount rate was simply too high (i.e., at the upper end of estimates for risky projects). These technical concerns, which otherwise might have been ignored, were given greater prominence given the political drive towards investment and competitiveness.

In response to these concerns, in $1998 \mathrm{HMT}$ commissioned an internal 'task force' to examine the Green Book discounting guidance. The task force aimed to: 1) clarify procedures for dealing with optimism bias; 2) specify the parameters of the social rate of time preference, ${ }^{14}$ and 3 ) examine the issue of discounting for long-run projects.

\section{The Role of the DDR Literature}

The task force was concerned with ensuring that updates to the Green Book were backed by convincing theory and robust empirical evidence. Between 1998 and 2001, the task force

\footnotetext{
12 See e.g., Labour Party Conference Speeches by Tony Blair as Prime Minister in 1997 (http://www.britishpoliticalspeech.org/speech-archive.htm?speech=203) and 1999 (http://www.theguardian.com/politics/1999/sep/28/labourconference.labour14).

${ }^{13}$ This erroneous belief could have stemmed from HMT (1997) Appendix to Annex B, paragraph 19, entitled "Rough and Ready Techniques". The clearest guidance on the origins of the $6 \%$ discount rate can be found in paragraphs 6- 15 in the Appendix to Annex G of HMT (1997).

${ }^{14}$ The Green Book uses a social time preference (STP) rate based on the Ramsey Rule: STP $=\rho+\eta$, where $\rho$ is the pure rate of time preference, $\eta$ is the elasticity of marginal utility and $g$ is the growth rate of consumption. These parameters were re-evaluated in the 2003 update.
} 
became aware of the academic literature on DDRs, in particular the papers by Weitzman (1998, 1999, 2001), Gollier (2002a, 2002b), and Newell and Pizer (2001, 2004), as well as an influential paper by David Pearce and David Ulph (1995). It was important that these ideas were published in reputable journals and were being advanced by "outstanding academic economists.” In fact, many UK civil servants and practitioners that we interviewed described the rationale for DDRs as the 'Weitzman effect'.15

The task force review of the literature raised concerns among several important political constituencies. For example, trade unions were concerned that the update would facilitate further privatisation, while supporters of Private Finance Initiatives (PFIs) were concerned that the results of the review would discourage PFI projects. ${ }^{16}$ Input from academics on the supply-side was important for navigating and addressing these conflicting concerns. So too was input from key personalities, to which we turn next.

\section{The Role of Key Personalities}

Professor David Pearce was one of the most influential brokers of the demand and supply sides of the UK market for ideas in environmental economics. Pearce had served as the chief advisor on environment in the Thatcher government, had a strong network in government and a research team - the Centre for Social and Economic Research on the Global Environment (CSERGE) - at the Department of Economics, University College London (UCL). Given his long-standing interest in BCA and social discounting, in 2002, Pearce began to cultivate an understanding of the latest discounting theory within government spending departments, particularly among Chief Economists. ${ }^{17}$

First, in 2002, Pearce invited Gollier to present his work on social discounting to the department of economics at UCL. Members of CSERGE attended this seminar and

\footnotetext{
${ }^{15}$ This is despite email correspondence among senior government economists at the time suggesting some scepticism of Weitzman's work (1998, 2001).

${ }^{16}$ PFIs share the costs of public infrastructure between the private sector and the government and are a way to establish Pubic Private Partnerships (PPP). PFls were a key proposal of the Blair government.

17 David Pearce's formidable contribution to national and international environmental policy, and his considerable capabilities as a policy broker, was summarised after his death in 2005 (see Convery 2007).
} 
subsequently summarised Gollier's arguments for DDRs, alongside the contributions from Weitzman (1998; 2001), for Professor Pearce.

Pearce knew that the Green Book update would need to meet the requirements of 'evidencebased policy making'. With this in mind, he proposed that Oxera, a consulting firm that worked on government policy, conduct a detailed review of the evidence on DDRs. The study was funded by the (now defunct) Office of the Deputy Prime Minister (ODPM) and the Department of Environment, Food and Rural Affairs (DEFRA). This funding structure had the advantage of ensuring the support of the civil service while avoiding the involvement of politicians. ${ }^{18}$ The Oxera (2002) study examined the papers by Weitzman and Gollier, as well as other strands of economics, to illustrate the implications of DDRs for public investments such as flood defences, nuclear power, the social cost of carbon, and transport.

\section{Passing the Test of Time}

The draft government guidelines, which followed the recommendations of Oxera (2002), were made public in early 2003. Government officials that we interviewed recalled that there were no major criticisms of the new Green Book following its release. Our interviewees agreed that the evidence presented in the Oxera report was important, even pivotal, in generating agreement and fending off objections to the new guidelines. Indeed, the Green Book heavily cites the Oxera (2002) report along with the papers by Weitzman and Gollier.

Most importantly, the new guidelines have passed the test of time. For example, in 2013, HMT held a workshop that presented evidence on discounting from the previous decade to representatives from various government departments. Academics ${ }^{19}$ presented research

\footnotetext{
${ }^{18}$ The project fee was $£ 20,000$, shared equally by ODPM and DEFRA. $£ 10,000$ was regarded as the upper limit of funding, beyond which the involvement of ministers would have been likely. Interviewees were divided about whether sharing funding was explicitly designed to keep the project under the political radar. ${ }^{19}$ These included Christian Gollier, Mark Freeman, David Maddison, Antony Millner, and the authors of this paper. Their contributions included presentations of Freeman (2010), Heal and Millner (2013) and Groom and Maddison (2013). See: http://www.Ise.ac.uk/geographyAndEnvironment/News\%20archive/GreenBook.aspx
} 
confirming the previous results. This evidence strengthened the support for the existing guidance and led to DDRs being retained in the Green Book in the 2017 update. Figure 2 summarizes the timeline of the policy change process for social discount rates over the past 20 years, starting with key papers and presentations that were relevant to the UK policy changes.

To summarize, the UK became the first government with formal guidelines that differentiated between the long-term and the short-term, achieved using the discount rate term structure (i.e., DDRs). The necessary conditions for the changes to the Green Book's discounting guidance in 2003 included the political demand, the supply of a defensible idea developed and presented by reputable economists, and an energetic and shrewd brokering of the two sides of the ideas market by Professor David Pearce, who built a case for change that overcame inertia and opposition.

\section{THE DIFFUSION OF DDR POLICY}

Other countries have since followed the lead of the United Kingdom in adopting changes to discounting guidance. This section examines how these changes came about, in particular whether they were triggered domestically (and were independent of the UK experience) or through a "policy diffusion" process.

Interviewees in the United Kingdom believed that the international reputation of the Green Book was "highly" or "extremely" important in raising the profile of DDRs as a policy choice elsewhere. For example, the UK experience was highlighted by the Organisation for Economic Development and Cooperation (OECD) at an international meeting of finance and environment officials (Hepburn, 2007). In addition, many governments from lower- or middle-income countries visit HMT to build capacity in public expenditure management. However, because the views of our UK-based interviewees are likely biased, we also interviewed officials from two countries that have adopted DDRs - France and Norway and two countries that have not adopted DDRs - the Netherlands and the United States. 
These interviews suggest that the UK's Green Book did play an important role in the DDR policy diffusion process, but was one of several determining factors.

\section{France}

In France, DDRs have been recommended in three government reports -- Lebègue (2005), Gollier (2010) and Quinet (2013). Lebègue (2005) first introduced DDRs for risk-free projects. Gollier (2010) extended the framework to risky projects. In 2013, the guidelines for risky projects were revised by Quinet (2013). We briefly review the development of these three reports and then assess the impact of the UK experience.

The Lebègue (2005) report, commissioned by the French Commissariat générale du Plan (more recently known as France Strategie), promulgated guidance on risk-free projects, with discount rates falling from $4 \%$ to $2 \%$ after 30 years, as shown in Figure $1 \mathrm{~b}$. The theoretical arguments for DDRs that formed the core advice to the French government came from various contributions by Christian Gollier, which extended the Ramsey Rule to incorporate persistent uncertainty in growth (Gollier 2008; 2012).

The Gollier (2010) report, commissioned by the Sarkozy government, retained DDRs for risk-free projects and extended the guidance to embody project-specific risk and the correlation of costs and benefits with the macro economy (systematic risk). A consequence of this approach, however, was high discount rates for some spending departments (e.g., transport). These departments resisted the recommendations, which were not implemented. ${ }^{20}$

The Quinet (2013) report, commissioned under the Hollande government, started with the Gollier (2010) report's recommendations on project risk, but recommended lower risk

\footnotetext{
${ }^{20}$ The Gollier Report recommended a Consumption Capital Asset Pricing Model (CCAPM) approach to discounting, which incorporates a risk premium reflecting systematic project risk. This premium is positive for pro-cyclical projects like transport infrastructure since the benefits are positively correlated with the macroeconomy. Estimates of the project "beta" in the Gollier report lead to risk premiums for transport of more than $4 \%$.
} 
premiums. ${ }^{21}$ This was acceptable to the spending departments, and represented a pragmatic compromise of various ethical and practical positions (e.g., Lebègue 2005, p 102). The final compromise was also achieved through discussions with representatives from trade unions. French guidance now recommends a $2.5 \%$ risk-free discount rate, declining to $1.5 \%$ after 2070. For risky projects, a risk premium of $\beta^{*} 2 \%$ is recommended, rising to $\beta^{*} 3 \%$ in 2070 , where $\beta$ is the project "beta,". ${ }^{22}$

How important was the UK experience to developments in France? Given that the French government benefitted directly from Gollier's advice on the theory (Gollier 2010), one might expect little need for a UK exemplar. However, Lebègue (2005) favourably cites the Green Book (Lebègue 2005, p 46), and our interviewees also suggest that the UK experience provided a helpful precedent for the French to adopt DDRs in principle.

\section{United States}

The prospect of using DDRs in BCA in the United States emerged around 2010, when the US Interagency Working Group (IAWG) on the Social Cost of Carbon ${ }^{23}$ provided guidance on the appraisal of government projects, ${ }^{24}$ specifying that "intergenerational projects" should be subjected to a flat discount rate of $2.5 \%$ for their duration (IAWG 2010; Sunstein 2014). ${ }^{25}$ The need for an IAWG focussing on the Social Cost of Carbon (SCC) arose from a 2007 Supreme Court Ruling that $\mathrm{CO}_{2}$ should be regulated as an air pollutant. ${ }^{26}$ This meant that regulatory changes with real impacts on carbon emissions, such as the Corporate Average

\footnotetext{
${ }^{21}$ New theoretical results, subsequently published in Gollier (2012) and Gollier (2016), shifted the focus of the Gollier and Quinet reports away from DDRs for risk-free projects towards the term structure of the project risk premia.

${ }^{22}$ A positive $\beta$ reflects a positive correlation between project benefits and growth, leading to a larger discount rate. A negative $\beta$, reflects a project with insurance type properties, and has the opposite effect on the discount rate.

${ }^{23}$ An Interagency Working Groups (IAWG) is a group of federal agencies within the executive branch of the US government, which allows for cross-agency discussions on a specific regulatory and/or policy issue.

${ }^{24}$ This was carried out under executive order 12866.

${ }^{25}$ By comparison, general guidance on regulatory analysis, which is set by Office of Management and Budget Circular A-4 (OMB 2003), is to employ a flat discount rate of $7 \%$ (for projects displacing private capital) or $3 \%$ (if displacing consumption).

${ }^{26}$ See https://www.law.cornell.edu/supct/html/05-1120.ZS.html
} 
Fuel Efficiency (CAFE) standards, would henceforth require precise estimates of the SCC (USEPA 2010).

Papers and Personalities in the US

The IAWG (2010) recommendations were heavily influenced by the academic literature on DDRs. Weitzman $(1998,2001)$ and Newell and Pizer $(2001,2003)$ and the empirical papers by Groom et al. (2007) and Hepburn et al. (2008) are prominently cited. Indeed, the flat $2.5 \%$ rate is a straightforward compromise between two of the time series interest rate models presented by Newell and Pizer (2003) (See Figure 1d). ${ }^{27}$

Academics such as Newell and Pizer played an important influence in the IAWG recommendations. At the time, (2007-2010), Pizer was a senior economist on the President's Council of Economic Advisers and was previously a research fellow at RFF, Newell was a senior research fellow at RFF, and both had been at Duke University. The 'revolving door' between academia, think tanks (e.g., RFF) and government is quite common among environmental economists in the US. An important institutional mechanism in the United States is the Intergovernmental Personnel Act (IPA), which places academics in government positions for 2 year periods. Other prominent environmental economists, such as Michael Greenstone, Elizabeth Kopits, and Joseph Aldy, also served in government positions through the IPA, and were also pivotal in ensuring that the SCC became part of the U.S. government guidelines for BCA.

\section{Evidence of UK policy diffusion}

Is there any evidence of policy diffusion from the United Kingdom? The Green Book is cited in both the IAWG (2010a, p23 ) and USEPA (2010, Ch 6, p16-17) guidelines), as is Oxera (2002), Pearce et al. (2003), and Groom et al. (2005). Pizer himself influenced the Green

\footnotetext{
${ }^{27}$ Newell and Pizer (2003) estimate an AR1 mean reverting and random walk model.
} 
Book changes through interviews with the team working on the Oxera (2002) report. Other interviewees confirm that the influences on policy ran in both directions across the Atlantic.

\section{A second attempt}

Another attempt to change the US guidelines for BCA occurred in 2011, in response to concerns that the $2.5 \%$ flat rate would apply to costs and benefits at all points of time solely because of the inter-generational horizon of the project or regulation. On behalf of the USEPA and the OMB, Maureen Cropper (University of Maryland and RFF) organised an expert panel/workshop on the topic of intergenerational discounting and DDRs at RFF in Washington. ${ }^{28}$ The panel concluded that the use of DDRs, as in France and the UK, would help to harmonise the treatment of costs and benefits across all projects, rather than treating projects with different time horizons differently.

The conclusions of the workshop were reported directly to OMB and USEPA officials, and disseminated more broadly by Arrow et al. $(2013 ; 2014)$. This was followed in 2014 by a high-level policy session at the American Economic Association meeting in Philadelphia. Papers extolling the virtues of DDRs were presented (e.g., Cropper et al. 2014, Gollier 2014) and Kenneth Arrow served as a discussant. Yet the paper by Cass Sunstein (2014), who was responsible for convening the IAWG on the SCC, asserted that the benefits of changing discounting policy did not exceed the internal institutional and political costs. The tone of his article is summed up by a paraphrased closing statement: 'if it ain't badly broke, don't get anywhere near it' (Sunstein 2014, p 55).

US guidance on discounting has thus far remained unchanged, despite the RFF workshop and the expert opinion of the RFF and AEA panels, and supporting presentations and papers. While the Green Book is cited in the IAWG and USEPA guidelines, our interviewees

\footnotetext{
${ }^{28}$ A detailed account of the questions the workshop was charged with addressing can be found at: http://www.rff.org/files/sharepoint/Documents/Events/Workshops\%20and\%20Conferences/110922Discounting/Charge Questions to the Committee.pdf
} 
agreed that the British and French precedent was not decisive in making the argument for DDRs in the US.

In sum, despite the high-quality supply of ideas on DDRs from US academics, it seems to have been difficult to successfully broker the ideas market. Sunstein (2014) argues that the problem is that the policy transactions costs were too high. Whether a more powerful and charismatic broker might make a difference is debated. Time may tell, as the National Academy of Sciences committee on the SCC raised the issue of DDRs once again in its January 2017 report (NAS 2017, CH6). Thus, the story of DDRs continues to unfold in the US.

\section{Norway}

In 2011, an expert committee was commissioned by Royal Decree in Norway to review the government's guidance on BCA, including discounting. This was a reaction to two problems perceived by the Ministry of Finance concerning the country's approach to project appraisal. First, as in France, the practice of using a discount rate that reflected project-specific risk allowed too much discretion and failed to select projects satisfactorily (according to our interviewees). Second, given the developments in the literature (e.g., Weitzman 1998; Gollier 2002a; 2002b; 2012; Newell and Pizer 2003), there were doubts in the Ministry of Finance about whether long-term projects were being properly evaluated using a constant discount rate over time.

The expert committee reported directly to the Ministry of Finance, indicating strong channels of engagement between government and academia. The committee chair, Professor Kåre Hagen, convened a meeting of domestic and international experts at the Norwegian School of Economics (NHH) Bergen in May 2012. Academics at the meeting ${ }^{29}$ helped to diffuse policy experience between countries, including discussing the UK experience.

\footnotetext{
${ }^{29}$ Invited experts included Weitzman, Gollier, and both authors, among others. See http://nyttekostweb.sharepoint.com/Pages/default.aspx.
} 
Although the UK experience did not trigger the policy change in Norway, the proposed guidance in Norway was qualitatively consistent with the UK Green Book, with DDRs for risk-free discount rates starting at $2.5 \%$ and declining to $2 \%$ after 30 years (see Figure 1c). As with the French case, interviewees described the UK experience as providing reassurance that the policy change was sensible.

\section{The Netherlands}

Guidance on BCA in the Netherlands is reviewed every seven years, with the most recent review, in 2014-5, including a commission on discounting. This review process included presentations to the Ministry of Finance by three outside experts on discounting. ${ }^{30}$ The technical report (CPB 2015) submitted to the government clearly summarized the literature on DDRs up until 2015, including Gollier (2014; 2015), and the UK Green Book was cited as standard practice. Although the Ministry of Finance accepted, in principle, the validity of a declining risk-free discount rate, based on uncertainty in growth, it did not recommend DDRs because the real interest rate was already $\mathrm{o} \%$ and a decline to negative risk-free rates was considered problematic.

Instead, CPB (2015) recommended a flat discount rate of $3 \%$ for the appraisal of all government projects, reflecting a systematic risk premium, and indicating the adoption of the "dual discounting" literature (e.g., Weikard and Zhu 2005, Hoel and Sterner 2007). ${ }^{31}$ The Netherlands Environmental Assessment Agency is now undertaking research to formalise changing relative prices in BCA guidance..$^{2}$

\footnotetext{
${ }^{30}$ Christian Gollier, Mark Freeman, and Ben Groom were invited as outside experts. Also present were several academics from the Netherlands including Aart de Zeeuw, Rob Aalbers (CPB) and Herman Volleburgh (EEA).

${ }^{31}$ Dual discounting recommends different discount rates for different commodity groups. For example, high rates might apply to consumption and lower rates might apply to environmental goods, reflecting their increasing scarcity relative to consumption.

${ }^{32}$ The commission was influenced by Baumgartner et al (2014) and Drupp (2016), who built on Weikard and Zhu (2005), and Hoel and Sterner (2007).
} 
The policy changes in the Netherlands appear to have been less reliant on entrepreneurial idea brokers than in the UK or France. Rather, well-defined and well-informed institutions (e.g., the Central Planning Bureau - CPB, the Netherlands Environment Agency) fulfilled the brokering role, thus reducing the need for charismatic policy entrepreneurs.

\section{CONCLUSIONS AND LESSONS LEARNED}

The experience with the successful deployment and dissemination of DDRs in the UK, France, and Norway suggests that academic economists have been able to significantly influence major policy guidance. Our interviews and analysis reveal three main conditions that must be met on the demand and supply sides of the policy making process before ideas can become reality. These conditions yield insights that in turn give rise to five important lessons for academic economists seeking to change policy.

\section{Demand and Supply-side Conditions}

Three conditions are necessary for advances in economic theory to find their way into policy. First, the "supply" of an idea from an academic economist must be of reasonable quality. Although Nobel Prize-winning ideas are not always necessary, in the words of our interviewees, government "gatekeepers" must find the ideas "persuasive enough" so that policymakers can feel confident that the academic work is "sound" and that they will not lose their jobs from deploying a flawed economic idea (Leaver, 2009). Here the perceived quality of the authors is as important as the quality of the work. That is, an idea from an "outstanding academic economist" is more likely to be incorporated into policy than the same idea put forward by an economist that lacks such a reputation. Such "outstanding" academics convey legitimacy and have authoritative or charismatic power in the sense of Foucault (1991). Christian Gollier and Martin Weitzman provide good examples in the France and UK cases, respectively. The late Kenneth Arrow's participation in the RFF workshop may still prove to be influential in the US. 
Second, there must be strong "demand" for the idea so that a suitable policy window can be opened. Political preconditions are important (Kingdon and Thurber, 1984). Existing theories and evidence will be applied when the prevailing political agenda (e.g. productivity and competitiveness in the UK) values them most, as reflected in the rapid adoption of DDRs in the UK, for example.

Third, in the absence of well-functioning institutions, a sufficiently energetic and influential policy entrepreneur (Mintrom, 1997) is needed to play the critical role of broker. This is not simply a matter of connecting the supply with the demand and facilitating a transaction. The policy entrepreneur must be able to "blast through" the inertia and status quo bias of government processes and institutions and make a difference (Convery 2007, Sunstein, 2014). In the US, environmental non-governmental organizations often play this key role in overcoming inertia and converting ideas into policy. Examples include RFF (on discounting), the Environmental Defense Fund (on the adoption of catch shares that give property rights to fishermen), and the Sierra Club's 'beyond coal' campaign.

\section{Lessons for Academics}

This discussion suggests five lessons for academics seeking to have an impact on policy.

1. There are diminishing marginal returns to the quality of your paper. Perceived quality does matter, but so does the perceived authority of the author. Beyond a certain point, polishing an idea further will not help if the other conditions for policy impact are not present.

2. Ideas clearly do matter - they are the cogs that drive history (Grayling, 2009). But the time is not always right for an idea to become policy. Academics seeking to have policy impact may need to be patient. It may take several decades before your idea takes hold. For instance, natural capital accounting is a very recent addition to UK government policy, even though the core theory was developed in the 1970s. Another example is the adoption of dual-discounting in the Netherlands: this idea was not 
new; it had been "waiting on the beach" to catch the next "big wave" (Kingdon 1995, p165).

3. There may be an advantage to connecting your ideas to energetic and influential policy entrepreneurs. Such connections can occur through direct personal relationships with such entrepreneurs, or through your ideas reaching them by means of conference presentations, press announcements, or other channels. (However, see \#4 next).

4. Institutions matter. The strength of institutions (e.g., the existence of formal government procedures for reviewing academic literature) determines the importance of "pushy" personalities in driving policy forward. In the UK and France, links between academics and government departments are often ad hoc, despite various academic panels. Pearce and Gollier, respectively, had to push policy forward. In contrast, the institutions in the Netherlands made personalities less important. The US Intergovernmental Personnel Act formalises academic influence to some degree. Our view is that institutions to ensure input from all academics, not just the energetic and pushy personalities, could improve policymaking. 33

5. Don't expect perfection. Policymakers will consider guidance from theory and empirical research to be just that - guidance - and, in practice, other political or practical considerations are likely to be important, if not decisive. For example, the DDRs in the United Kingdom were based on US data and implemented in a highlysimplified manner to reduce the cognitive burden on civil servants.

In conclusion, we have argued that the successes and failures of efforts to change social discounting policy over the past 15 years can be understood as the intermediation of supply and demand in a market for ideas. Like any market, the ideas market can fail. Nor does the ideas market necessarily lead to good 'evidence-based policy making'. On the contrary, the demand side can lead to 'policy-based evidence making'. For example, the 2006 Deaton

\footnotetext{
${ }^{33}$ According to our interviews, HM Treasury plans to organise more annual updates of the Green Book, while in France, there are proposals for a high-level panel to provide regular input on policy matters.
} 
report, which comprehensively reviewed the World Bank's historical research practices, argued that the World Bank trumpeted apparent early research results on the effects of trade liberalisation on poverty because it fit the prevailing policy, even though the jury was "very much still out” (Deaton et al. 2006, p52-54). Reinhart and Rogoff (2010), whose article alluded to the positive association between austerity and growth, was similarly trumpeted by many governments pursuing austerity, despite no claim of causality by the authors and welldocumented arithmetic errors. Both examples look like demand-side cherry-picking. The World Bank case may have occurred because demand, supply, and the brokers were all in the same body. The Reinhart and Rogoff case may have arisen due to the perceived authority of the authors and the journal in which the research was published. Additional checks and balances to ensure research quality might have helped, as would an unwillingness to defer to authority even when research results support prior beliefs.

Overall, we have argued that policy changes in social discounting occurred through the combined influence of supply (key papers and presentations), demand (political preconditions), and sometimes brokers (personalities). This suggests that a better understanding of these processes will help academic economists work more effectively to improve policy-making in the future. 


\section{References}

Ainslie, G. (1992). Picoeconomics: The strategic interaction of successive motivational states within the person. Cambridge: Cambridge University Press.

Arrow, K. (1982). "The rate of discount on public investments with imperfect capital markets" in Lind, R. C. (ed) Discounting for time and risk in energy policy, RFF Press, New York, USA.

Arrow, K. J. (1999). "Discounting, Morality, and Gaming” in Portney, P. R., Weyant, J. P. (eds). Discounting and intergenerational equity. Resources for the Future, Washington DC, US

Arrow, K., Cropper, M., Gollier, C., Groom, B., Heal, G., Newell, R., Nordhaus W. D., Pindyck, R. S., Pizer, W.A., Portney, P.R., Sterner, T., Tol, R.S.J., and Weitzman M.L. (2013). Determining benefits and costs for future generations. Science, 341(6144), 349-350.

Arrow, K., Cropper, M., Gollier, C., Groom, B., Heal, G., Newell, R., Nordhaus W. D., Pindyck, R. S., Pizer, W.A., Portney, P.R., Sterner, T., Tol, R.S.J., and Weitzman M.L. (2014). Should governments use a declining discount rate in project analysis? Review of Environmental Economics and Policy, 8(2) pp. 145-163.

Barro, R. J. (1999). Ramsey meets Laibson in the neoclassical growth model. Quarterly Journal of Economics, 1125-1152.

Braun, M (2009). The evolution of emissions trading in the European Union- the role of policy networks, knowledge and policy entrepreneurs. Accounting, Organisation and Society, 34, pp 469487.

Baumgärtner S, Klein A-M, Thiel D, Winkler K (2015), Ramsey discounting of ecosystem services. Environmental and Resource Economics, 61:273-296

CPB (2015). Rapport werkgroep discontovoet 2015.

https://www.rijksoverheid.nl/binaries/rijksoverheid/documenten/rapporten/2015/11/13/rapportwerkgroep-discontovoet-2015-bijlage/rapport-werkgroep-discontovoet-2015-bijlage.pdf

Convery F.J. (2007). Making a difference - how environmental economists can influence the policy process - a case study of David W Pearce. Environ Resource Econ (2007) 37:7-32. DOI

10.1007/s10640-007-9116-5

Cox, J. C., Ingersoll, J. E., \& Ross, S. A. (1981). A Re-examination of Traditional Hypotheses about the Term Structure of Interest Rates. The Journal of Finance, 36(4), 769-799.

Cropper, M. L., Aydede, S. K., \& Portney, P. R. (1994). Preferences for life saving programs: how the public discounts time and age. Journal of Risk and Uncertainty, 8(3), 243-265.

Cropper, M. L., Freeman, M. C., Groom, B., \& Pizer, W. A. (2014). Declining discount rates. The American Economic Review, 104(5), 538-543.

Cropper, M. L. \& Laibson, D. (1999). "The Implication of Hyperbolic Discounting for Project Evaluation" in Portney, P. R., Weyant, J. P. (eds). Discounting and intergenerational equity. Resources for the Future, Washington DC, US.

Deaton, A., Banerjee, A., Lustig, Rogoff, K. and Hsu, E. (2006) “An Evaluation of World Bank Research, 1998 - 2005”. http://siteresources.worldbank.org/DEC/Resources/847971109362238001/726454-1164121166494/RESEARCH-EVALUATION-2006-Main-Report.pdf

Dolowitz, David P. and David Marsh. 2000. Learning from abroad: The role of policy transfer in contemporary policy making. Governance, 13(1), 5-23. 
Drupp M A (2016). Limits to Substitution between Ecosystem Services and Manufactured Goods and Implications for Social Discounting. Environmental and Resource Economics. doi:10.1007/s10640016-0068-5

Feldstein, M.S. (1965) ‘The Derivation of Social Time Preference Rates’, Kyklos, XVIII.2, pp. 277-287.

Foucault, M (1991). Governmentality. In G. Burchell, C Gordon, and P. Miller (Eds), The Foucault Effect: Studies in governmentality, Chicago (pp 87-104).

Frederick, S., Loewenstein, G., \& O'Donoghue, T. (2002). Time discounting and time preference: A critical review. Journal of Economic Literature, 40(2), 351-401.

Freeman, M. C., \& Groom, B. (2015). Positively gamma discounting: combining the opinions of experts on the social discount rate. The Economic Journal, 125(585), 1015-1024.

Freeman M.C. and Groom, B (2016). 'How certain are we about the certainty equivalent long-run social discount rate?' Journal of Environmental Economics and Management, 79, 152-168.

Gollier, C. (1997). “Discounting an Uncertain Future,” Mimeo, Univer. of Toulouse

Gollier, C. (2002a). Discounting an uncertain future. Journal of Public Economics, 85, 149-166.

Gollier, C. (2002b). Time horizon and the discount rate. Journal of Economic Theory, 107, 463-473.

Gollier, C. (2004). Maximizing the expected net future value as an alternative strategy to gamma discounting. Finance Research Letters, 1(2), 85-89.

Gollier, C. (2008). Discounting with fat-tailed economic growth. Journal of Risk and Uncertainty (2008) 37:171-186.

Gollier, C. (2013). Pricing the planet's future: the economics of discounting in an uncertain world. Princeton University Press.

Gollier, C. (2014). Discounting and Growth. American Economic Review, 104(5): 534-37

Gollier, C. (2016). Gamma discounters are short-termist, Journal of Public Economics, vol. 142, issue C, 83-90.

Groom, B., Hepburn, C. J., Koundouri, P., \& Pearce, D. (2005). Discounting the future: the long and the short of it. Environmental and Resource Economics, 32(4).

Groom, B., Koundouri, P., Panopoulou, K., \& Pantelides, T. (2004). Model Selection in discounting the distant future. Department of Economics, University College London Discussion paper, 4(02).

Groom, B., Koundouri, P., Panopoulou, K., \& Pantelides, T. (2007). Discounting the distant future: How much does model selection affect the certainty equivalent discount rate? Journal of Applied Econometrics, 22 (3),

Groom B (2014). 'Discounting'. Ch 7 in 'The Handbook of the Economics of Climate Change Adaptation', Markandya, A, Galarega, I. and Sainz de Murieta, E. (eds), Routledge.

Heal, G., and Millner, A. (2013). Discounting under disagreement (No. w18999). National Bureau of Economic Research.

Hagen, K.P., Berntsen, S., Bye, B., Hultkrantz, L., Nyborg, K., Pedersen, K.R., Sandsmark, M., Holst Volden, G. and Åvitsland, G., (2012). Cost-benefit analysis: Review from a committee appointed by Royal Decree of 18 February 2011. Official Norwegian Reports, NOU 2012: 16.

Henderson, N., \& Bateman, I. (1995). Empirical and public choice evidence for hyperbolic social discount rates and the implications for intergenerational discounting. Environmental and Resource Economics, 5(4), 413-423. 
Hepburn, C. (2007). Use of discount rates in the estimation of the costs of inaction with respect to selected environmental concerns. OECD Papers,7(9), 1-42.

Hoel, M. and T. Sterner (2007) 'Discounting and relative prices”, Climatic Change, vol. 84, PP 265280)

Hepburn, C., Koundouri, P., Panopoulou, E., and Pantelidis, T. (2009). Social discounting under uncertainty: A cross-country comparison. Journal of Environmental Economics and Management, 57(2), 140-150.

HMT (1997). Guidelines on Cost Benefit Analysis. HM Treasury, UK.

HMT (2003). Guidelines on Cost Benefit Analysis. HM Treasury, UK.

IAWG (2010) Interagency Working Group on Social Cost of Carbon. Social Cost of Carbon for Regulatory Impact Analysis under Executive Order 12866. February. United States

Government. http://www.whitehouse.gov/sites/default/files/omb/inforeg/for-agencies/Social-Costof-Carbon-for-RIA.pdf.

Kahneman, D., \& Tversky, A. (1979). Prospect theory: An analysis of decision under risk. Econometrica, 263-291.

Keynes, John M. (1936) [2006]. General theory of employment, interest and money. Atlantic Publishers \& Dist.

Kingdon, J. W. (1995). Agendas, Alternatives, and Public Policies ( $2^{\text {nd }}$ edition). New York: HarperCollins College Publishers

Kingdon, J. W., Thurber, J. A. (1984). Agendas, alternatives, and public policies (Vol. 45). Boston: Little, Brown.

Koopmans, T. C. (1960). Stationary ordinal utility and impatience. Econometrica, 287-309.

Koopmans, T. C. (1972). Representation of preference orderings over time. Decision and organization, 57, 100.

Laibson, D. (1997). Golden eggs and hyperbolic discounting. The Quarterly Journal of Economics, 443-477.

Leaver, C. (2009). Bureaucratic minimal squawk behavior: Theory and evidence from regulatory agencies. The American Economic Review, 99(3), 572-607.

Lebegue, D. (2005), Revision du taux d.actualisation des investissem- net publics. Rapport du groupe de experts, Commisariat Generale de Plan.

http://catalogue.polytechnique.fr/site.php?id=324\&.leid=2389.

Lind, R. C.(1982a). Discounting for time and risk in energy policy, (ed) RFF Press, New York, USA.

Lind, R. C.(1982b). "A primer on the major issues relating to the discount rate for evaluating national energy options", $\mathrm{CH} 2$ in Discounting for time and risk in energy policy, RFF Press, New York, USA.

Loewenstein, G., \& Prelec, D. (1992). Anomalies in intertemporal choice: Evidence and an interpretation. The Quarterly Journal of Economics, 573-597.

Lucas R.E. (1978) Asset Prices in an Exchange Economy, Econometrica, Vol. 46, No. 6., pp. 1429-1445

Mintrom, M. (1997). Policy entrepreneurs and the diffusion of innovation. American Journal of Political Science, 41(3), 738-770. 
NAS (2017). Valuing Climate Changes: Updating Estimation of the Social Cost of Carbon Dioxide. National Academy of Sciences. DOI: 10.17226/24651 http://www.nap.edu/24651

Newell, R., Pizer, W. (2001). Discounting the Benefits of Future Climate Change Mitigation. Pew Center on Global Climate Change, Dec 2001.

Newell, R. G. \& Pizer, W. A. (2003). Discounting the distant future: How much do uncertain rates increase valuations? Journal of Environmental Economics and Management, 46, 52-71.

OMB (1972). Guidelines for Benefit-Cost Analysis of Federal Programs.

https://obamawhitehouse.archives.gov/sites/default/files/omb/assets/a94/aog4.pdf

OMB (2003). Circular A-4 Regulatory Analysis.

https://obamawhitehouse.archives.gov/sites/default/files/omb/assets/regulatory matters pdf/a4.pdf

Oxera (2002). The Selection of a Social Time Preference Rate to be Used in Long-Term Discounting.

Oxera ltd, Oxford. http://www.oxera.com/Publications/Reports/2002/

Pearce, D., Groom, B., Hepburn C, Koundouri, P. (2003). Valuing the future: recent advances in social discounting. World Economics 4, 121-141.

Pearce, D.W. and Ulph, D. (1995) 'A social discount rate for the United Kingdom', CSERGE working paper, later published in D.W. Pearce (1999) (Ed), Environmental Economics: Essays in Ecological Economics and Sustainable Development, Cheltenham, Edward Elgar.

Portney, P. R., Weyant, J. P. (1999). Discounting and intergenerational equity. Resources for the Future, Washington DC, US

Quinet, E., 2013. L'évaluation socio-économique en période de transition, Rapport du groupe de travail présidé par Émile Quinet, Commissariat général à la stratégie et à la prospective Tome I, Rapport final, Juin.

Ramsey, F. P. (1928). A mathematical theory of saving. The Economic Journal, 38(152), 543-559.

Reinhart C. M. and Rogoff, K.S. (2010). Growth in a Time of Debt, American Economic Review, vol. 100(2), pages 573-78.

Sabatier, P. A. (2006). Policy change and learning: An advocacy coalition approach (theoretical lenses on public policy). The Perseus Books Group Boulder, Colorado.

Samuelson, P. A. (1937). A note on measurement of utility. The Review of Economic Studies, 4(2), $155-161$.

Schelling, T. C. (1999). “Intergenerational Discounting” in Portney, P. R., Weyant, J. P. (eds).

Discounting and intergenerational equity. Resources for the Future, Washington DC, US

Sterner $\mathrm{T}$ and Persson $\mathrm{M}$ (2008). An even sterner review: Introducing relative prices into the discounting debate. Rev Environ Econ Policy (2008) 2 (1): 61-76.

Sunstein, Cass R.. (2014). On Not Revisiting Official Discount Rates: Institutional Inertia and the Social Cost of Carbon. American Economic Review, 104(5).

Thaler, R. H. (1981). "Some Empirical Evidence on Dynamic Inconsistency". Economic Letters. 8 (3): 201-207.

USEPA (2010). Guidelines for Preparing Economic Analyses. United States Environmental Protection Agency, Washington DC. EPA 240-R-10-001.

https://yosemite.epa.gov/ee/epa/eerm.nsf/vwAN/EE.../EE-0568-50.pdf 
Waters T. and Waters D. (2015). "Politics as Vocation" pp. 129-198, and "Discipline and Charisma" pp. 59-72 in Weber's Rationalism and Modern Society, edited and translated by Tony Waters and Dagmar Waters, Palgrave MacMillan

Weitzman M. L. (1986). The Share Economy: conquering stagflation. Harvard University Press.

Weitzman, M. L. (1998). Why the far-distant future should be discounted at its lowest possible rate. Journal of environmental economics and management,36(3), 201-208.

Weitzman, M. L. (1999). “Just keep on discounting, but...”. In P.Portney and J.Weyant (eds), Discounting and Intergenerational Equity, Washington DC, Resources for the Future, 23-30.

Weitzman, M. L. (2001). Gamma discounting. American Economic Review, 260-271. 


\section{Appendix: List of Interviewees}

We conducted interviews with a dozen government officials and academics in mid-2016, following the interview guide in the on-line supplementary materials. The list of interviewees and their institutional affiliations are presented below.

\begin{tabular}{|l|l|l|l|}
\hline$\#$ & Name & Country & Institution during policy window \\
\hline $\mathbf{1}$ & Joe Grice & UK & HM Treasury \\
\hline $\mathbf{2}$ & Joeseph Lowe & UK & HM Treasury \\
\hline 3 & Robin Smale & UK & Oxera Ltd \\
\hline 4 & Michael Spackman & UK & NERA Ltd \\
\hline 5 & Christian Gollier & France & Toulouse School of Economics \\
\hline 6 & Emile Quinet & France & $\begin{array}{l}\text { Paris School of Economics - Ecole des Ponts } \\
\text { ParisTech; Chair of “Quinet Commission" }\end{array}$ \\
\hline 7 & Geir Avitsland & Norway & Ministry of Finance, Norway \\
\hline $\mathbf{8}$ & Kare Hagen & Norway & $\begin{array}{l}\text { NHH; Chair of Expert Committee reporting to } \\
\text { Ministry of Finance, Norway }\end{array}$ \\
\hline 9 & Herman Vollebergh & Netherlands & $\begin{array}{l}\text { Netherlands Environmental Assessment } \\
\text { Agency, University of Tilburg }\end{array}$ \\
\hline 10 & Aart de Zeeuw & Netherlands & $\begin{array}{l}\text { Department of Economics, University of } \\
\text { Tilburg }\end{array}$ \\
\hline $\mathbf{1 1}$ & Maureen Cropper & USA & $\begin{array}{l}\text { Department of Economics, University of } \\
\text { Maryland, Resources For the Future }\end{array}$ \\
\hline & & USA & $\begin{array}{l}\text { Council of Economic Advisers, Resources for } \\
\text { the Future, Sanford School of Public Policy, } \\
\text { Duke University. }\end{array}$ \\
\hline
\end{tabular}




\section{Figures}

\section{Figure 2: Timeline and Key Personalities, Papers, and Presentations}

\section{in the Policy Change Process}

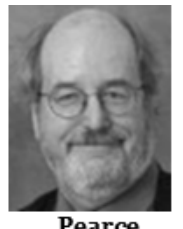

Pearce

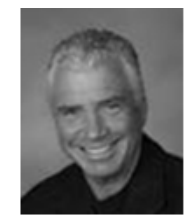

Weitzman
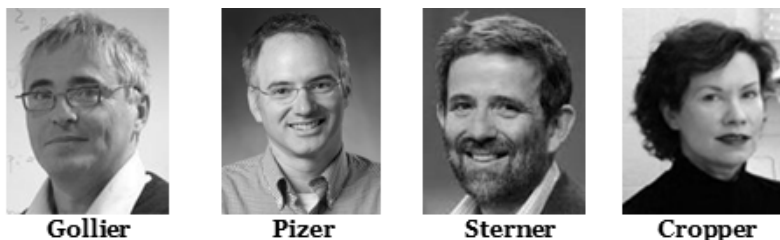

Cropper

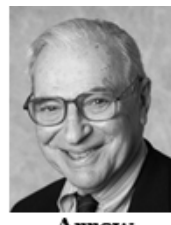

Arrow

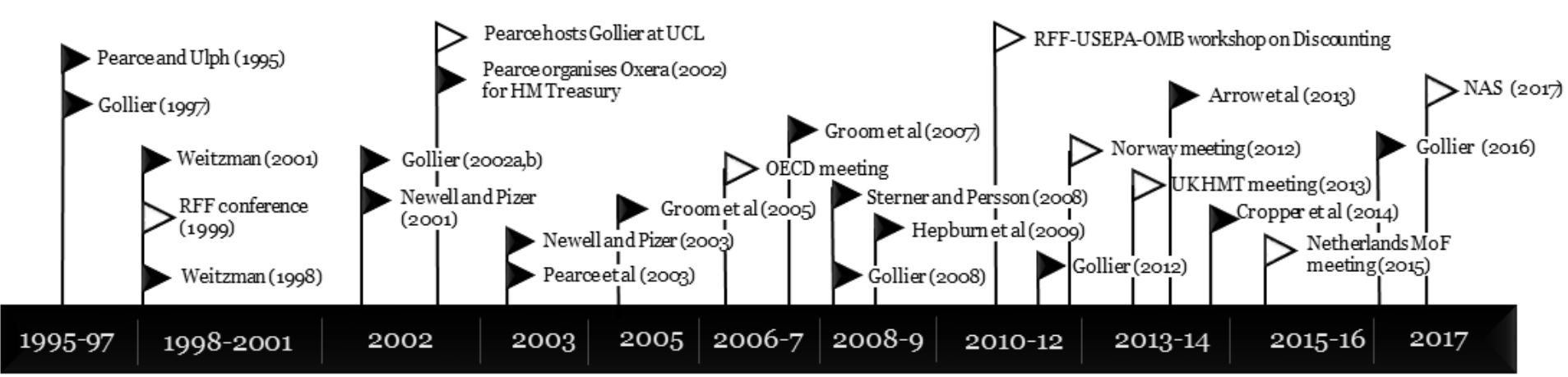

Research and Development

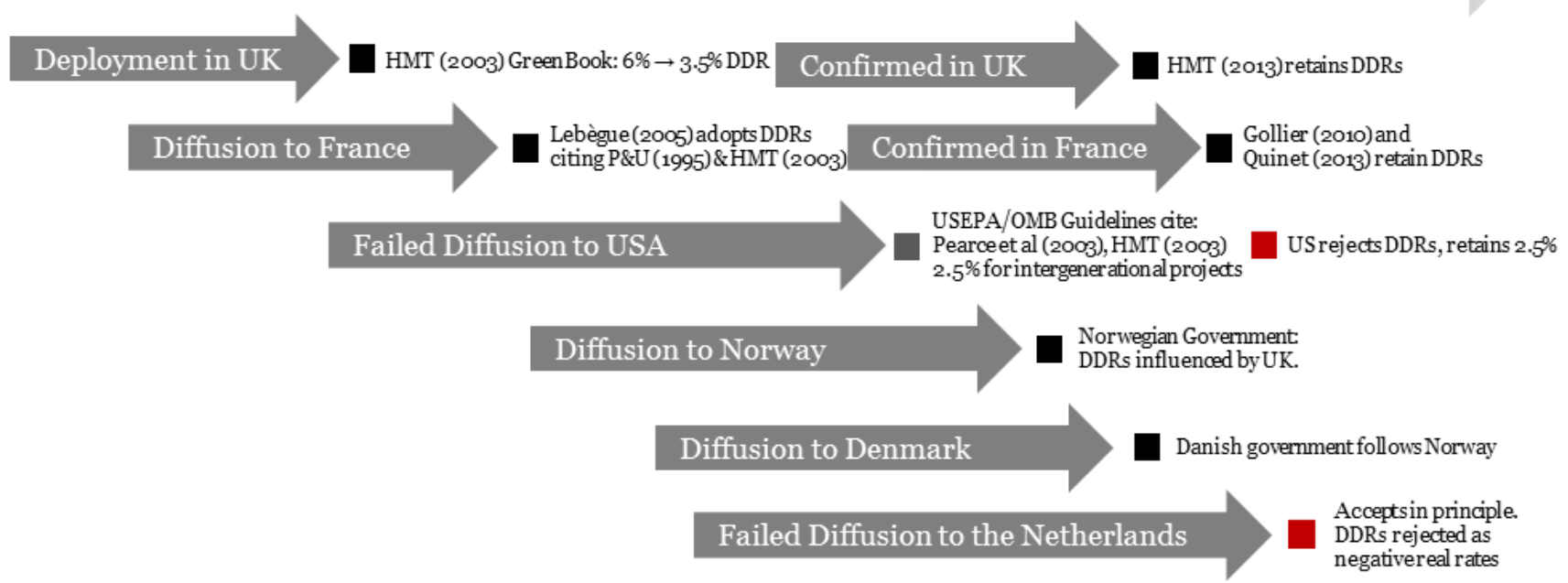


Figure 1: Declining Social Discount Rate Schedules for (a) United Kingdom; (b)

France; (c) Norway; (d) United States of America34

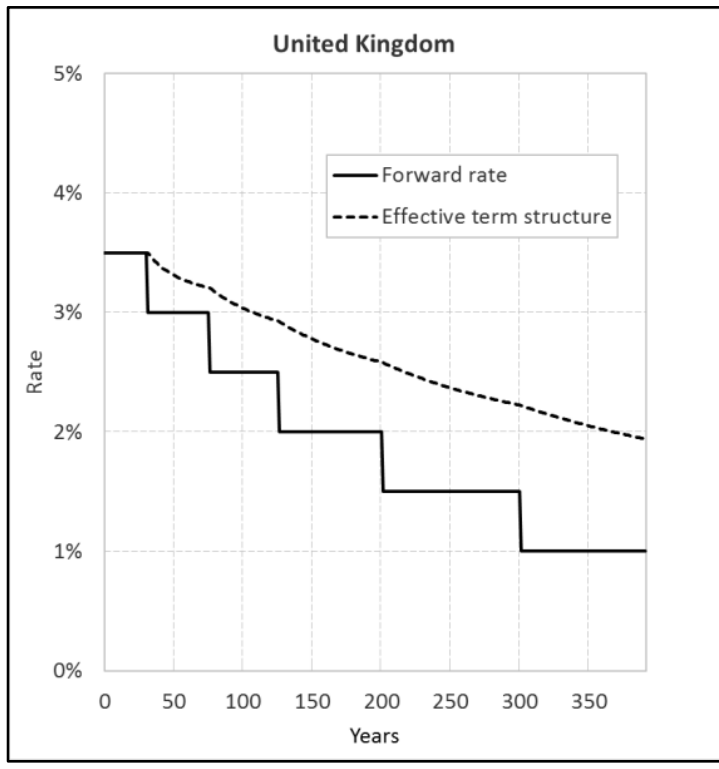

(a)

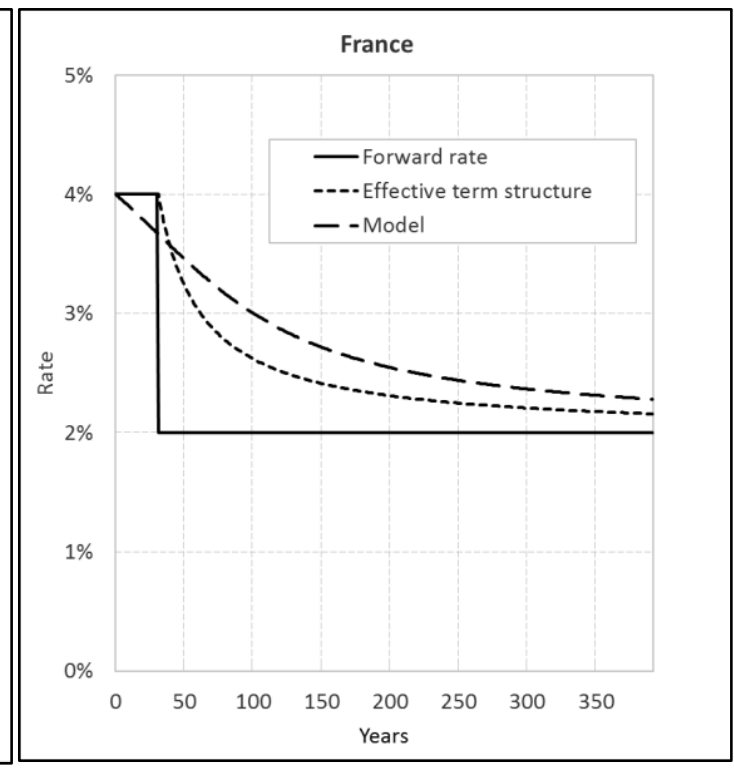

(b)

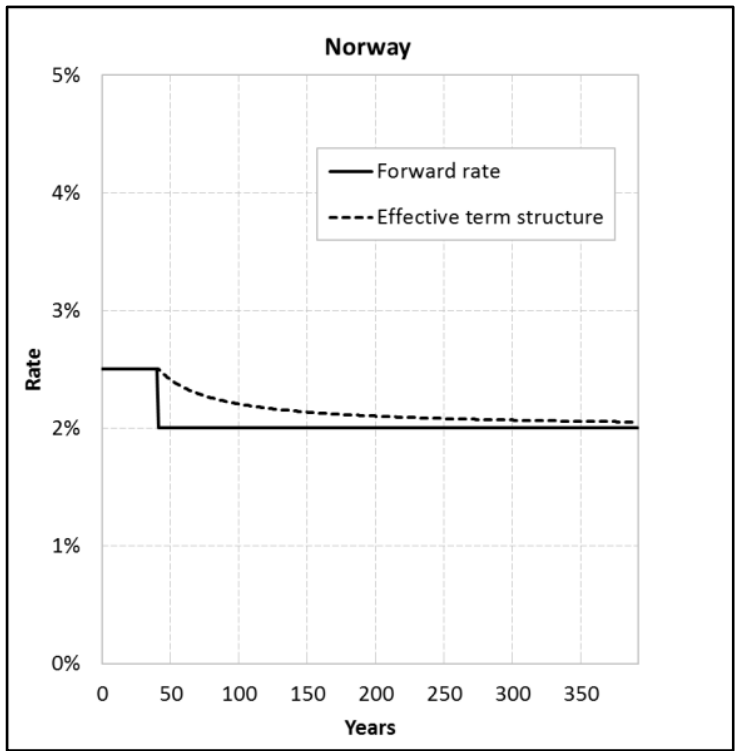

(c)

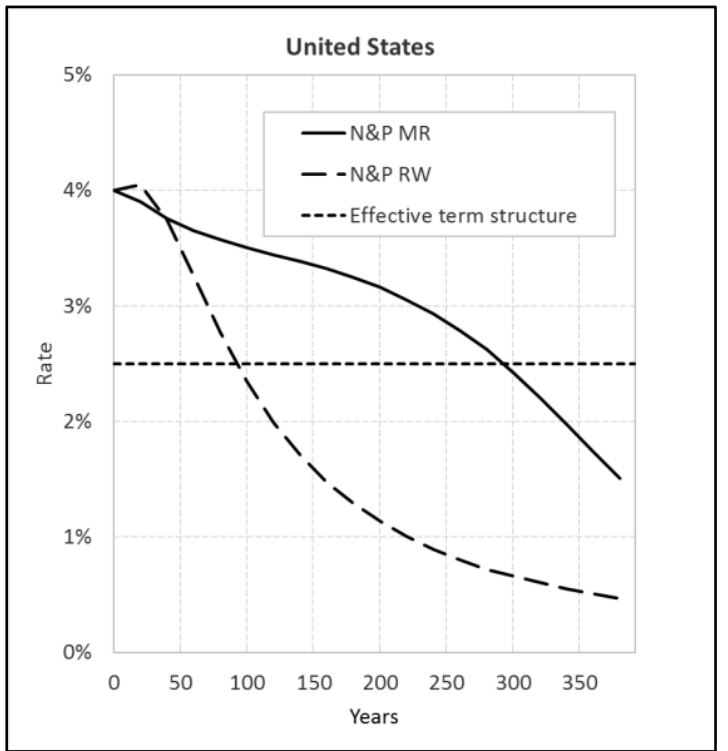

(d)

${ }^{34}$ Sources: Groom (2014), Newell and Pizer (2003). 